\title{
IMPLEMENTATION OF MODIFICATION GAME METHODS TO IMPROVE BREASTSTROKE SWIMMING SKILLS
}

\author{
Ruslan Abdul Gani ${ }^{1}$, Hasanuddin Jumareng², Kuswahyudi ${ }^{3}$, Oman Unju \\ Subandi $^{4}$, Edi Setiawan ${ }^{5}$ \\ Universitas Singaperbangsa Karawang ${ }^{1}$, Universitas Halu Oleo Kendari ${ }^{2}$, Universitas \\ Negeri Jakarta ${ }^{3,4}$, Universitas Suryakancana, Cianjur ${ }^{5}$ \\ ruslan.abdulgani@staff.unsika.ac.id
}

\begin{abstract}
The breaststroke is a swimming style that is loved by everyone because it is so easy to do. The purpose of this study was to improve breaststroke swimming skills in the 2018/2019 physical education study program students through the application of the modified game method. The method used in this research is a classroom action research methodology research design by Kemmis and Mc.Taggart. he subjects in this study were 31 students of the PJKR study program who took the aquatic learning course II, the results of this study were from the initial test data that 8 students were in the complete category or about $26 \%$, there was an increase in the cycle 1, 20 students were included in the category. complete or about $65 \%$, and in cycle 2, there was a very large increase with 29 students in the complete category or around $94 \%$, this research was in accordance with the set target, namely $90 \%$. he conclusion of this study is that the application of the modified game method is effective in improving breaststroke swimming skills in physical education study program students class of 2018/2019
\end{abstract}

Keywords: Modification game, skills, breaststroke

Accepted: 9th of July 2021

Correspondence author: Ruslan Abdul Gani, Universitas Singaperbangsa Karawang, Indonesia. E-Mail: ruslan.abdulgani@staff.unsika.ac.id

DOI http://dx.doi.org/10.31851/hon.v4i25404 doi

\section{(1) (2)}

Jurnal Halaman Olahraga Nusantara licensed under a Creative Commons Attribution-ShareAlike 4.0 International License

\section{INTRODUCTION}

Education is a conscious effort made to increase the quality of thought patterns or perspectives and insights so that changes for the better and optimally increase the potential in individuals. Potential in humans there are two things potential in a positive or negative direction depending on each individual and the environment which has a very big influence on potential changes in humans. In realizing the national development goals in the field of education, it must be a top priority in order to lead to a prosperous future (Mustafa et al., 2019). Therefore, 
Ruslan Abdul Gani, Hassanudin Jumareng, Kuswahyudi, Oman Unju Subandi, Edi Setiawan, (2021)

Implementation Of Modification Game Methods To Improve Breaststroke Swimming Skills

\section{HALAMAN Jendral A. Yani Street Lorong Gotong Royong 9/10 Ulu OLAHRAGA

create positive potentials in students in order to create positive behavior both in terms of cognitive, affective and psychomotor (Bandi, 2011). This is in line with the meaning of education in the Law of the Republic of Indonesia Number 20 of 2003 that education is a conscious and planned effort to create an atmosphere of learning and the learning process so that students actively develop their potential for religious spiritual strength, self-control, personality, intelligence, noble morals, as well as the skills needed by him, society, nation and state.

Physical Education is education that has a major contribution to education in general, the most important thing is education through the experience of movement which can guarantee the growth of children physiologically and anatomically and children's development cognitively, affective and psychomotor (Bayu Nugraha, 2015). A very important part in physical education is the psychomotor domain or the ability to move, the other two aspects, namely the affective and cognitive domains will come out of the students by themselves (Supriyadi, 2017). Physical education is a field of study that studies physical movements to increase the overall degree of human fitness including physiological and anatomical, emotional and character development aspects of students. This is also emphasized by Paturusi, (2012) that physical education must be able to provide direction to children in carrying out their movement activities in order to develop physical, social, emotional, and moral aspects. Physical education emphasizes student suitability, motor development, knowledge of healthy life (Putri et al., 2021). The learning process of physical education must be carried out from an early age so that children's growth and development can be optimal in terms of the health of their organs, their movement activities, the ability to think and control their emotions (Solihin et al., 2013). So physical education is part of education in general which has a very large positive contribution to the development and growth of students in an effort to increase the degree of physical fitness comprehensively. In physical education we need to make an assessment of the learning process and outcomes, authentic assessment, relevant and meaningful 
Ruslan Abdul Gani, Hassanudin Jumareng, Kuswahyudi, Oman Unju Subandi, Edi Setiawan, (2021)

for teachers and students (Dyson, 2014). if we don't do this then learning will not have a good impact on students. In developing children's movement skills, physical education planning is needed in order to achieve a complete degree of health including cognitive, psychomotor and affective aspects (Mustafa \& Winarno, 2020).

The success of the learning process is strongly influenced by several factors, including the facilities and infrastructure and methods of learning, with supported facilities to improve the quality of learning (Daryono \& Almy, 2021). The choice of the method is very important because so that the learning objectives can be achieved in accordance with the objectives we expect, one of which is the modified game method which is very enjoyable for students. With the rapid development of science in education, it is very possible for physical education practitioners and teachers to carry out modifications in learning, the most creative and innovative way is to modify the learning process to make it look more attractive and students will be more enthusiastic and active in the learning process (Hidayat Taufiq \& Kurniawan Deddy, 2015). Game modification in learning can attract students' interest and motivation, modification is made due to the demands of learning renewal to solve problems found in the field such as boredom of students, lack of exploration of the potential for student movement. The modification referred to can be in the form of changes to the area of the field, the equipment used and the rules of the game (Gustiana, 2011). With the modification it will make students interested in the learning process to take place happily and the teacher will be simpler in preparing the teaching (Sobarna, 2018). The purpose of modification in physical education is as an expression that is channeled through movement activities in order to achieve educational goals (Reid, 2013). The teacher must know the characteristics of students before teaching, so that the material presented can be understood by students(Cobanoglu et al., 2019). This means that the assignment that is delivered must be in accordance with the characteristics of the students we are teaching. with this modification one of the 
Ruslan Abdul Gani, Hassanudin Jumareng, Kuswahyudi, Oman Unju Subandi, Edi Setiawan, (2021)

Implementation Of Modification Game Methods To Improve Breaststroke Swimming Skills

\section{HALAMAN Jendral A. Yani Street Lorong Gotong Royong 9/10 Ulu OLAHRAGA Palembang South Sumatera

ways that can be done by the teacher so that the learning process can see changes in the progress of students and help these changes. Therefore the assignment must be adjusted to the characteristics of the students who are learning. This modification method is an effort that teachers can do so that the learning process reflects DAP. From the two statements above, the author can conclude that game modification is a change in the rules of the game, the form of the game, the equipment used is simpler by paying attention to the characteristics of students and does not completely eliminate the game rules, moving can also improve health as well as physical fitness to be able to develop a fair play attitude to work together with others (Arisman \& Agun Guntara, 2021).

Lecturers should provide the learning process to students how to learn to find (Discovery), create, and understand the concept of knowledge, competence in movement and affective in themselves. The more optimal activity of movement, creativity, and student participation, the hope of developing their potential and potential learning resources around them will be achieved (Suwiwa, 2015). Learning breaststroke swimming includes several stages including: 1) Body Position, 2) Leg Movement, 3) Breathing Movement, 4) Arm Movement, 5) Overall Movement. According to Rulianto, Safari, \& Mulyanto, (2016) breaststroke swimming is swimming with the chest facing the water surface in a streamlined state. Both legs kick outwards, while both hands are extended in front. Both hands are opened to the side like a splitting motion of water so that the body can move faster forward.The breaststroke technique consists of several movements, namely: start, body position, arm movements (outer sweep and inner sweep), leg movements, breathing in, and coordination between arm movements, leg movements and breath-taking movements. The definition of breaststroke swimming according to the FINA regulations (de Natation, 2013) from the start of doing the first hand draw after the start and every reversal, the body must remain face down (chest facing the water). Turning around on your back (back facing the water) is not allowed even once. Throughout the race one cycle must be one hand 
Ruslan Abdul Gani, Hassanudin Jumareng, Kuswahyudi, Oman Unju Subandi, Edi Setiawan, (2021)

draw and one leg kick must be taken. Every complete cycle, a portion of the swimmer's head must break the surface of the water. In breaststroke swimming must be considered asymmetrical physical components which include strength, flexibility if this physical component is bad, then training must be done to increase strength and flexibility and physiotherapy to improve the quality of the breaststroke swimming technique (Higgs et al., 2017). The development of breaststroke techniques has experienced developments in swimming techniques with the flat stroke technique used by swimmers to modern breaststroke swimming techniques (Olstad et al., 2017)

In the learning process of swimming for students in the Physical Education and Recreation Study Program in the Aquatic II course which includes butterfly swimming and breaststroke, which are compulsory courses that must be taken by students, and what researchers do in this research process is breaststroke swimming, because it is seen that many students have difficulty in the learning process of breaststroke swimming. Based on observations made by researchers that the completeness of students in the practice of breaststroke swimming is $62.8 \%$ complete, $37.2 \%$ are incomplete, from these data the learning process of breaststroke swimming will not be achieved. Thus lecturers must be smart in choosing methods that can increase mastery of breaststroke swimming skills, because with precisely the lecturers choosing the learning method, success in the learning process will be achieved. Through this game modification method, the learning process will be fun while still paying attention to the characteristics of students, and learning objectives can be achieved, with a gradual learning process from easy, moderate to difficult levels, so that students can understand the whole learning concept.

Based on previous research entitled "Aquatic Learning Model Based on Traditional Games to Improve Primary School Students' Swimming Skills" (Susanto \& Listianingsih, 2019). The result of his research is that the developed traditional game model can improve the mastery of swimming skills in elementary 
Ruslan Abdul Gani, Hassanudin Jumareng, Kuswahyudi, Oman Unju Subandi, Edi Setiawan, (2021)

Implementation Of Modification Game Methods To Improve Breaststroke Swimming Skills

HALAMAN

OLAHRAGA

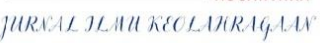

Accredited

email jurnal: jurnalhon@univpgri-palembang.ac.id situs web: http://www.univpgri-palembang.ac.id

SINTA 3

school students. The differences in this study, the researcher emphasizes the variation aspects of water games with tools and without tools, so the novelty in this study the researcher is on game variations with tool modifications. and without tools. The purpose of this study is to increase breaststroke swimming skills by using game modifications.

\section{METHOD}

The research design used was a model from Kemmis and Mc.Taggart, which was in the form of a cycle or round of activities which included the design stages at each cycle, namely: (1) Planning, (2) Acting, (3) Observation / Observing, (4) Reflection / Reflecting, and a revision of the planning will be held in the repeat cycle if it is still needed. The subjects in this study were students of the 2018/2019 class of physical education study program who took the Aquatic Learning II course totaling 31 students. There are two data collection techniques, quantitative data, namely the breaststroke swimming skills test and qualitative data, namely data taken from the results of field notes and observations of each daily activity. The game modification method given is as follows:

Table 1. Modified Breaststroke Style Swimming Game

\begin{tabular}{|c|c|c|c|}
\hline No & Game Name & Purpose & Steps \\
\hline 1 & Standing Frog & Arm muscle endurance. & $\begin{array}{l}\text { Stand in the pool and stand on one foot } \\
\text { in front or the position of the legs in the } \\
\text { kangkang then move the arms } \\
\text { simultaneously backwards. }\end{array}$ \\
\hline 2 & Circular Motion & $\begin{array}{l}\text { Strengthens the triceps } \\
\text { muscles. }\end{array}$ & $\begin{array}{l}\text { Standing in the pool, turn your palms } \\
\text { down using a float board for a circular } \\
\text { motion on the triceps pad. Place the } \\
\text { board above the water surface in front of } \\
\text { you. put your hand in the middle of the } \\
\text { board, then pull your arm to your side, } \\
\text { press the board down. }\end{array}$ \\
\hline 3 & $\begin{array}{l}\text { Push ups in the } \\
\text { pool }\end{array}$ & $\begin{array}{l}\text { The strength and } \\
\text { endurance of the } \\
\text { latismismus dorsi and } \\
\text { triceps muscles. }\end{array}$ & $\begin{array}{l}\text { Face the wall of the klam and place your } \\
\text { hands apart as wide as you know by the } \\
\text { pool. No need to jump to generate } \\
\text { power to move yourself up and out of } \\
\text { the water using only the strength of your } \\
\text { arms. let your body relax then lower it } \\
\text { back down. }\end{array}$ \\
\hline 4 & Push it down & Endurance & Extend your arms to the sides of your \\
\hline
\end{tabular}


Ruslan Abdul Gani, Hassanudin Jumareng, Kuswahyudi, Oman Unju Subandi, Edi Setiawan, (2021)

\section{HALAMAN Jendral A. Yani Street Lorong Gotong Royong 9/10 Ulu OLAHRAGA Palembang South Sumatera \\ Accredited \\ situs web: http://www.univpgri-palembang.ac.id

\begin{tabular}{|c|c|c|c|}
\hline & & $\begin{array}{l}\text { latissimus dorsi muscles, } \\
\text { lower chest and } \\
\text { abdominal muscles. }\end{array}$ & $\begin{array}{l}\text { palms facing your kebwah (shoulder } \\
\text { abduction). Lower your arms to your } \\
\text { side, back to their original position. }\end{array}$ \\
\hline 5 & $\begin{array}{l}\text { Paddle a float } \\
\text { board }\end{array}$ & $\begin{array}{l}\text { Endurance of the } \\
\text { trapezius, latissimus } \\
\text { dorsi and core muscles. }\end{array}$ & $\begin{array}{l}\text { Hold the buoy next to your body with } \\
\text { both hands. Extend the board to the side } \\
\text { and slowly bring it to the other side of } \\
\text { your body. Push the lower limit of the } \\
\text { board into the water and pedal the board } \\
\text { again. Remove the plank from the water } \\
\text { to return to the starting position. }\end{array}$ \\
\hline 6 & $\begin{array}{l}\text { Mountain climbing } \\
\text { motion }\end{array}$ & $\begin{array}{l}\text { Stretching: the } \\
\text { endurance of the } \\
\text { muscles in the upper leg } \\
\text { (hamstring muscles, } \\
\text { gluteus), the respiratory } \\
\text { resistance of the heart. }\end{array}$ & $\begin{array}{l}\text { Stand with your legs stranded. Bend the } \\
\text { back of the knee and then lift it to a hip } \\
\text { level (as if going up a ladder) back to } \\
\text { the starting position. }\end{array}$ \\
\hline 7 & $\begin{array}{l}\text { Butt } \\
\text { motion }\end{array}$ & Stretch. warming up. & $\begin{array}{l}\text { Start by standing straight with your feet } \\
\text { close to your sideways arms, push heels } \\
\text { from one leg towards your buttocks, do } \\
\text { it with one leg in a row (single) or } \\
\text { switch legs }\end{array}$ \\
\hline 8 & Chest passes & $\begin{array}{l}\text { Power of the pectoralis } \\
\text { anterior pectoralis } \\
\text { muscle of the triceps } \\
\text { deltoiddsn. }\end{array}$ & $\begin{array}{l}\text { Use a float board instead of using the } \\
\text { ball to increase the resistance of the } \\
\text { technique. Hold the board perpendicular } \\
\text { to the water and hold it on both sides. } \\
\text { Pull the board under the water and push } \\
\text { the board away from you like giving a } \\
\text { basketball pass to a partner. }\end{array}$ \\
\hline 9 & Bouncing motion & $\begin{array}{l}\text { Vertical leaps } \\
\text { (measurements of leg } \\
\text { strength) endurance of } \\
\text { the hamstrings, } \\
\text { quadriceps, and glutes. }\end{array}$ & $\begin{array}{l}\text { Start with your feet shoulder width apart } \\
\text { and hands above your head. Bend your } \\
\text { knees and squat until the water reaches } \\
\text { your chin (putting weight on your hips) } \\
\text { then jump up as high as you can. }\end{array}$ \\
\hline 10 & Punching & $\begin{array}{l}\text { Endurance of the } \\
\text { pectoralis, triceps and } \\
\text { deltoid muscles. }\end{array}$ & $\begin{array}{l}\text { Stand in the pool in a boxing position } \\
\text { and do the punch, jab, hook, uppercut }\end{array}$ \\
\hline 11 & Front kick & $\begin{array}{l}\text { Dynamic balance; } \\
\text { endurance of } \\
\text { quadriceps }\end{array}$ & $\begin{array}{l}\text { Stand in the boxer position, bend your } \\
\text { hips first then continue by extending } \\
\text { your legs forward as if you were hitting } \\
\text { the target. Performed alternating right } \\
\text { and left legs. }\end{array}$ \\
\hline 12 & Side kick & $\begin{array}{l}\text { Dynamic balance; } \\
\text { endurance of the } \\
\text { hamstring, gluteus } \\
\text { (especially gluteus } \\
\text { medius) and lumbar } \\
\text { abductor muscles. }\end{array}$ & $\begin{array}{l}\text { Stand with your legs stranded. start by } \\
\text { moving the hips away from the body } \\
\text { with the knees bent, kick straight } \\
\text { sideways as if kicking the target, try to } \\
\text { keep the kick from coming out of the } \\
\text { water surface }\end{array}$ \\
\hline
\end{tabular}


Ruslan Abdul Gani, Hassanudin Jumareng, Kuswahyudi, Oman Unju Subandi, Edi Setiawan, (2021)

Implementation Of Modification Game Methods To Improve Breaststroke Swimming Skills

HALAMAN

OLAHRAGA

Accredited

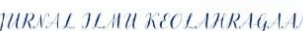

email jurnal: jurnalhon@univpgri-palembang.ac.id

situs web: http://www.univpgri-palembang.ac.id

SINTA 3

\section{RESULTS AND DISCUSSION}

Table 2. Data recapitulation of the Percentage of Breaststroke Swimming Skills students in cycle I

\begin{tabular}{ccccccc}
\hline No & Action & $\begin{array}{c}\text { Number of } \\
\text { students }\end{array}$ & Completed & Percentage & $\begin{array}{c}\text { Not } \\
\text { complete }\end{array}$ & Percentage \\
\hline $\begin{array}{l}\text { 1. } \\
\quad \begin{array}{l}\text { Preliminary } \\
\text { data }\end{array}\end{array}$ & 31 & 8 & $26 \%$ & 23 & $74 \%$ \\
2. & Cycle 1 & 31 & 20 & $65 \%$ & 11 & $35 \%$ \\
\hline
\end{tabular}

Based on the data in Table 1 there was an increase, seen from the initial test data there were 8 students or $26 \%$ who were included in the complete criteria, an increase in cycle 1 to 20 students or $65 \%$ and those who had not completed were reduced to 23 students or $74 \%$ to 11 student or $35 \%$. Based on these data, the results of breaststroke swimming skills in the first cycle still have not reached the expected target, so reflection must be done to create and determine the program in the next cycle.

Table 3. Data recapitulation of the Percentage of Breaststroke Swimming Skills students in cycle 2

\begin{tabular}{ccccccc}
\hline No & Action & $\begin{array}{c}\text { Number of } \\
\text { students }\end{array}$ & Completed & Percentage & $\begin{array}{c}\text { Not } \\
\text { complete }\end{array}$ & Percentage \\
\hline 1. & Preliminary & 31 & 8 & $26 \%$ & 23 & $74 \%$ \\
2. & data & & 20 & $65 \%$ & 11 & $35 \%$ \\
3. & Cycle 1 & 31 & 29 & $94 \%$ & 2 & $6 \%$ \\
\hline
\end{tabular}

It can be explained from the data in Table 2 of the results of this cycle II observing and seeing the skills of students doing breaststroke swimming.From 31 students, there are 29 students or $94 \%$ have met the completeness of the learning process with an average value of 75 . Based on the data from the results of cycle II learning breaststroke swimming using the modified game method has good criteria with these results meaning that it can be said to be complete. The following is the improvement data from the initial test to cycle 2 in the diagram below. 
Ruslan Abdul Gani, Hassanudin Jumareng, Kuswahyudi, Oman Unju Subandi, Edi Setiawan, (2021)

\section{OLATRAGA \\ Jendral A. Yani Street Lorong Gotong Royong 9/10 Ulu \\ Palembang South Sumatera \\ Accredited \\ email jurnal: jurnalhon@univpgri-palembang.ac.id situs web: http://www.univpgri-palembang.ac.id

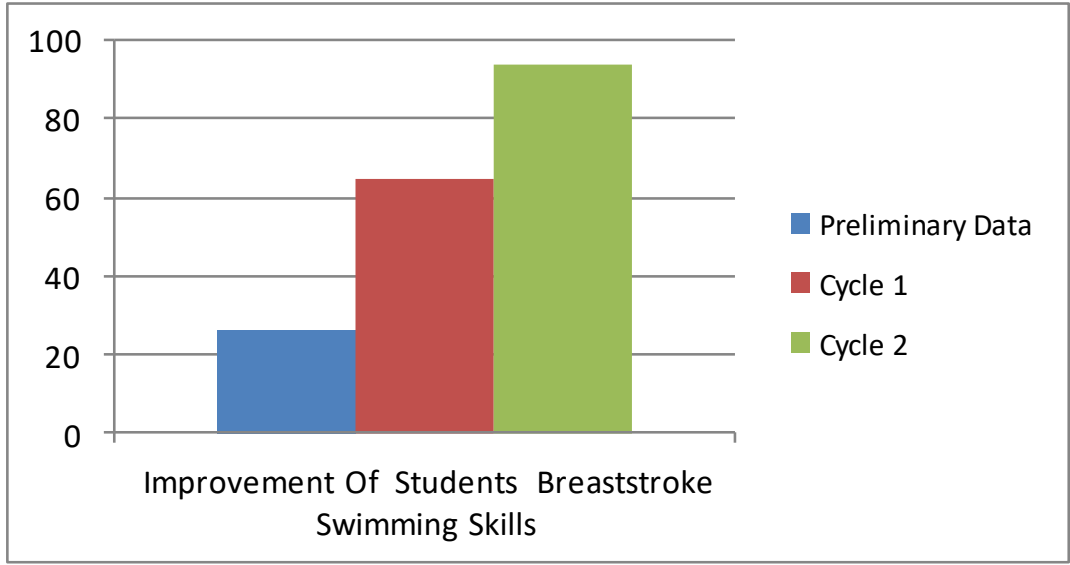

Figure 1. Diagram of the results of cycle 1 and cycle 2

Based on Figure 1, the results of the breaststroke swimming skills test on students from cycle 1 and cycle 2 have increased, from the initial test data $26 \%$ has increased in cycle I with a percentage of $65 \%$, and in cycle II has experienced a high increase with a percentage of $94 \%$, although there were 2 students who had not completed with a percentage of $6 \%$, but overall they reached the predetermined target of $90 \%$, so the treatment was stopped. Classroom Action Research with the application of the modified game method can make a positive contribution to breaststroke swimming skills.

\section{DISCUSSION}

Research The stages contained in learning breaststroke swimming are in the form of a test that has been made from planning, implementing observations and student learning outcomes. increasing breaststroke swimming skills can be seen in the presence of cycle 1 data. When the researchers carried out observations to students with the initial test of breaststroke swimming skills, it turned out that it needed to be improved. The result is that there are 31 students consisting of 25 male students and 6 female students, about 8 students who have met the complete criteria. After the initial data was collected then the researcher discussed with the partners as data analysis and reflection in making further lesson plans, to improve breaststroke swimming skills in research students giving treatment in the form of game modifications to improve breaststroke swimming skills. From the test data 
Ruslan Abdul Gani, Hassanudin Jumareng, Kuswahyudi, Oman Unju Subandi, Edi Setiawan, (2021)

Implementation Of Modification Game Methods To Improve Breaststroke Swimming Skills

\section{HALAMAN Jendral A. Yani Street Lorong Gotong Royong 9/10 Ulu OLAHRAGA Palembang South Sumatera \\ Accredited \\ JURAL JLHUKKOLDIRAQHAH \\ email jurnal: jurnalhon@univpgri-palembang.ac.id situs web: http://www.univpgri-palembang.ac.id

obtained from the first cycle there was an increase compared to the initial data that had been obtained. although the increase was not too big, learning to use the game modification approach was a solution in solving problems with breaststroke swimming skills. Even though there is an increase in cycle 1 in cycle 2 there must be an increase and improvement is needed in the learning process, in order to get optimal results in the mastery of breaststroke swimming skills in students.

Breaststroke swimming is a swimming that is different in its own technique because it is done with the body face down, beginning to do breaststroke swimming in a prone position on the shoulders parallel to the water surface, starting with stroking the arms backwards together after the start and reversal.(Hermawan \& Nurmasari, 2020), arm and leg movements sweep sideways and breathe with the shoulders raised, and breaststroke among the other swimming styles this style is the slowest style.

A swimmer in breaststroke swimming must pay attention to the average propulsion and the resistance caused when his swimming speed is continuous, so he must understand the regulation of the balance of force and energy to be effective and efficient.(Seifert et al., 2011). Currently, it has been developed to measure the level of energy released by swimmers with the name of the tool, namely intertial measurenment units (IMUs) (Magalhaes et al., 2015).

In the curriculum in schools in Indonesia, breaststroke swimming is included in the school curriculum at the elementary, middle and high school levels up to college. In accordance with the opinion Akbar, Priyono, \& Arhesa, (2020) that swimming learning material is material that is included in the scope of aquatic activities in the physical education curriculum and must exist at every level of elementary, junior high, high school to university level.

Learning breaststroke swimming will be easy to understand and can be done if you have mastered freestyle swimming because freestyle swimming is a style that must be mastered by students, freestyle swimming is the motther of swimming from of all the other styles. So the first style that must be taught to 
Ruslan Abdul Gani, Hassanudin Jumareng, Kuswahyudi, Oman Unju Subandi, Edi Setiawan, (2021)

students is freestyle, then butterfly, backstroke and finally breaststroke. This must be done because the breaststroke is different from the swimming technique itself, the freestyle is the same as the backstroke, only the body position is the backstroke, the backstroke is done on the back, the swimming technique is the same, the butterfly is the same as the freestyle, only the technique is done simultaneously, both arm movements and leg movements. Mastery of swimming so that it can be understood and students are able to do it must be with the game modification method in the water so as not to saturate and boring the students, by describing the modification of the tool with the game s students are not aware of the program given that it is very tiring, but designed fun so it doesn't feel tired because it's done with a happy mood. Lecturers must understand the psychology of students so that learning runs according to the desired goals, differences in motor skills must be an important concern for lecturers when providing teaching material, the ability of someone is different, some are fast, some are slow to be able to. The difference in student character in this learning interaction is a very important factor for lecturers to be able to develop learning methods or media to be more innovative and fun with variations in learning when learning is carried out (Sriningsih, 2017). Modification of the game which is carried out entirely by water with tools and help from friends is carried out in a pleasant learning atmosphere, there is no pressure on students so that all students enjoy learning breaststroke swimming. The learning process must have an interaction between lecturers and students in order to achieve learning objectives, students are given a positive stimulus and response so that they are critical of asking questions that do not understand it during the learning process.

This research was conducted based on findings in the field and field research studies. Research conducted by Rizky \& Siregar, (2019)with the title Research application of modified game methods to improve football dribbling skills, in this study that the modification in the learning process with games gives students interest in carrying out what is assigned or directed by the teacher or 
Ruslan Abdul Gani, Hassanudin Jumareng, Kuswahyudi, Oman Unju Subandi, Edi Setiawan, (2021)

Implementation Of Modification Game Methods To Improve Breaststroke Swimming Skills

\section{HALAMAN Tendral A. Yani Street Lorong Gotong Royong 9/10 Ulu OLAHRAGA

coach. So that the expected goal, the research carried out provides reinforcement that the modification of the game will improve the movement ability of students, the difference with the research that the researchers wrote on teaching material, namely on breaststroke swimming material with game modifications in water. Meanwhile, research related to the learning method carried out by Putra, Suranto, \& Sitepu, (2014) with the title of research on the effect of the part and overall method on breaststroke swimming skills, the results of this study were that using the part method was better than the part method. Overall because the part method is more focused on the parts of learning, it is different from the research that the researcher did on the method chosen by the researcher using the game modification method to improve breaststroke swimming skills, the equation is that using the right method will provide success in the learning process carried out.

Research conducted by Aritianto \& Hartoto, (2015) with the title of research on the effect of developing breaststroke swimming on breaststroke swimming skills, the results of the research were to provide treatment with a breaststroke swimming learning program to improve breaststroke swimming skills, the difference with research by researchers lies in the program given by the researcher uses game modifications, so it will be more fun for students who carry out the program given by the teacher, the equation is by providing a treatment program to improve breaststroke swimming skills.

The research conducted by Kusumadadi Apik \& Supriyono, (2016) with the title of research is an effort to improve learning outcomes of breaststroke swimming through learning media pichtograph. is the sample that he studied and the learning program that was designed. Research conducted by Sungkowo, Raharjo, \& Supriyono, (2012) with the title research development of swimming learning through the motor boat relay approach, the results of this study with a motor boat relay game development model approach to improve swimming ability in elementary school students, differences in research In this approach, the researcher prefers to modify the game with tools and without tools to make the 
Ruslan Abdul Gani, Hassanudin Jumareng, Kuswahyudi, Oman Unju Subandi, Edi Setiawan, (2021)

learning atmosphere more fun and interesting. The relevance of all these studies provides reinforcement that by applying a method, media and approach that is in accordance with the characteristics of students will provide convenience and increase the quality of good movement skills for students.

\section{CONCLUSION}

Based on the exposure and results of research conducted by researchers, there is a very significant increase with the application of modified game methods to improve breaststroke swimming skills, then the application of modified game methods is effective in increasing mastery of breaststroke swimming skills in physical education study program students 2018/2019. As a study, the next research can be carried out on other swimming styles in freestyle, butterfly and backstroke to improve the swimming quality of students.

\section{ACKNOWLEDGMENTS}

My gratitude goes to the Universitas Singaperbangsa Karawang who have provided support in the implementation of this research.

\section{REFERENCES}

Akbar, M. F., Priyono, A., \& Arhesa, S. (2020). Peningkatan hasil belajar gerak dasar renang gaya dada melalui metode pembelajaran renang shallow water method. Seminar Nasional Pendidikan, FKIP UNMA 2020, 453-460.

Arisman, A., \& Agun Guntara, R. (2021). The Research Of Students' Motor Ability In Archery Extracurricular. Jurnal Maenpo: Jurnal Pendidikan Jasmani Kesehatan Dan Rekreasi, 11(1), 13. https://doi.org/10.35194/jm.v11i1.1216

Aritianto, A., \& Hartoto, S. (2015). Pengaruh Pengembangan Pembelajaran Renang Gaya Dada Terhadap. Jurnal-Pendidikan-Jasmani, 03(02), 355-360.

Bandi, A. M. (2011). Abdullah: Dasar-Dasar Pendidikan Jasmani - Google Scholar. Jurnal Pendidikan JAsmani Indonesia, 8(April), 1-9. https://doi.org/https://doi.org/10.21831/jpji.v8i1.3477

Bayu Nugraha. (2015). Pendidikan Jasmani Olahraga Usia Dini. Jurnal Pendidikan Anak, 4(1), 557.

Cobanoglu, R., Capa-Aydin, Y., \& Yildirim, A. (2019). Sources of teacher beliefs 
Ruslan Abdul Gani, Hassanudin Jumareng, Kuswahyudi, Oman Unju Subandi, Edi Setiawan, (2021)

Implementation Of Modification Game Methods To Improve Breaststroke Swimming Skills

HALAMAN

OLAHRAGA

JURALJUHUKCOLDIRLQHA

Accredited

email jurnal: jurnalhon@univpgri-palembang.ac.id situs web: http://www.univpgri-palembang.ac.id

about developmentally appropriate practice: a structural equation model of the role of teacher efficacy beliefs. European Early Childhood Education Research Journal, 27(2),

195-207. https://doi.org/10.1080/1350293X.2019.1579547

Daryono, \& Almy, A. M. (2021). Peningkatan keterampilan bermain bola voli mahasiswa melalui latihan self check. Jurnal Halaman Olahraga Nusantara, 4(I), 89-99. https://doi.org/http://dx.doi.org/10.31851/hon.v4i1.5101

de Natation, F. I. (2013). FINA Swimming Rules. Lausanne: FINA. Available at: http://www. fina. org/H2O/docs/rules ....

Dyson, B. (2014). Quality physical education: A commentary on effective physical education teaching. Research Quarterly for Exercise and Sport, 85(2), 144-152. https://doi.org/10.1080/02701367.2014.904155

Gustiana. (2011). Pengaruh permainan modifikasi terhadap kemampuan motorik kasar dan kognitif anak usia dini. Jurnal Penelitian Pendidikan, Edisi $\operatorname{Khus}(2), 193-194$.

Hermawan, H. A., \& Nurmasari, K. (2020). Identifikasi kesulitan belajar renang gaya dada mahasiswa PJKR S1 angkatan 2018. Journal Pendidikana Jasmani Indonesia, 16(1), 18-27. https://doi.org/https://doi.org/10.21831/jpji.v16i1.31191

Hidayat Taufiq \& Kurniawan Deddy. (2015). Pengaruh Modifikasi Permainan Bolavoli Terhadap Kerjasama Siswa Pada Pembelajaran Pendidikan Jasmani, Olahraga Dan Kesehatan (Studi Pada Siswa Kelas X Boga 1 SMKN 3 Probolinggo). Jurnal Pendidikan Olahraga Dan Kesehatan, 03(1), 20-24.

Higgs, A. J., Pease, D. L., \& Sanders, R. H. (2017). Relationships between kinematics and undulatory underwater swimming performance. Journal of Sports Sciences, 35(10). https://doi.org/10.1080/02640414.2016.1208836

Kusumadadi Apik, \& Supriyono. (2016). Upaya meningkatkan hasil belajar renang gaya dada melalui media pembelajaran pictograph. ACTIVE: Journal of Physical Education, Sport, Health and Recreation, 5(1), 5-8. https://doi.org/https://doi.org/10.15294/active.v5i1.9315

Magalhaes, F. A. de, Vannozzi, G., Gatta, G., \& Fantozzi, S. (2015). Wearable inertial sensors in swimming motion analysis: a systematic review. Journal of Sports $\quad$ Sciences, $33(7), \quad 745$. https://doi.org/10.1080/02640414.2014.962574

Mustafa, P. S., \& Winarno, M. E. (2020). Pengembangan Buku Ajar Pengajaran Remedial Dalam Pendidikan Jasmani Untuk Mahasiswa S1 Pendidikan Jasmani Dan Kesehatan Universitas Negeri Malang. Multilateral Jurnal Pendidikan Jasmani Dan Olahraga, 19(1), 1-12. 
Ruslan Abdul Gani, Hassanudin Jumareng, Kuswahyudi, Oman Unju Subandi, Edi

https://doi.org/10.20527/multilateral.v19i1.7629

Mustafa, P. S., Winarno, M. E., \& Supriyadi. (2019). Penilaian Pendidikan Jasmani, Olahraga, dan Kesehatan pada Sekolah Menengah Pertama Negeri Kota Malang. Jurnal Pendidikan: Teori, Penelitian, Dan Pengembangan, $4(10)$, 1364-1379. https://doi.org/http://dx.doi.org/10.17977/jptpp.v4i10.12845

Olstad, B. H., Vaz, J. R., Zinner, C., Cabri, J. M. H., \& Kjendlie, P. L. (2017). Muscle coordination, activation and kinematics of world-class and elite breaststroke swimmers during submaximal and maximal efforts. Journal of Sports Sciences, 35(11), 1107-1117. https://doi.org/10.1080/02640414.2016.1211306

Paturusi, A. (2012). Manajemen pendidikan jasmani dan olahraga. Jakarta: Rineka Cipta.

Putra, S. A., Suranto, S., \& Sitepu, A. (2014). Pengaruh Metode Bagian Dan Metode Keseluruhan Terhadap Keterampilan Renang Gaya Dada. JUPE (Jurnal Penjaskesrek), 2(1).

Putri, R. A. S., Lanos, C. E. M., Lestari, H., \& Fajar, M. (2021). Student perception of the basic engineering learning model throught the play approach. Jurnal Halaman Olahraga NUsantara, 4(1), 114-124. https://doi.org/http://dx.doi.org/10.31851/hon.v4i1.5120

Reid, A. (2013). Physical education, cognition and agency. Educational Philosophy and Theory, 45(9), 921-933.

Rizky, O. B., \& Siregar, N. M. (2019). Penerapan metode permainan modifikasi untuk meningkatkan keterampilan dribbling sepakbola. Multilateral:Jurnal Pendidikan Jasmani Dan Olahraga, 18(1), 1-9. https://doi.org/http://dx.doi.org/10.20527/multilateral.v18i1.6561

Rulianto, G., Safari, I., \& Mulyanto, R. (2016). Penelitian Eksperimen pada Siswa di Adyas Aquatic Club Sumedang. Jurnal Pendidikan Guru Sekolah Dasar Penjas, 1(1).

Seifert, L., Leblanc, H., Herault, R., Komar, J., Button, C., \& Chollet, D. (2011). Inter-individual variability in the upper-lower limb breaststroke coordination. Human Movement Science, 30(3), 550-565. https://doi.org/10.1016/j.humov.2010.12.003

Sobarna, A. (2018). Penerapan Modifikasi Alat Bantu terhadap Minat Siswa dalam Pembelajaran Tolak Peluru. Jurnal Penelitian Pendidikan, 18(2), 103108. https://doi.org/10.17509/jpp.v18i2.12951

Solihin, R. D. M., Anwar, F., \& Sukandar, D. (2013). Kaitan antara status gizi, 
Ruslan Abdul Gani, Hassanudin Jumareng, Kuswahyudi, Oman Unju Subandi, Edi Setiawan, (2021)

Implementation Of Modification Game Methods To Improve Breaststroke Swimming Skills

\section{OLAHRAGA}

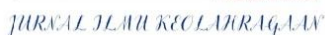

Jendral A. Yani Street Lorong Gotong Royong 9/10 Ulu Palembang South Sumatera

email jurnal: jurnalhon@univpgri-palembang.ac.id situs web: http://www.univpgri-palembang.ac.id
Accredited

SINTA 3

perkembangan kognitif, dan perkembangan motorik pada anak usia prasekolah (relationship between nutritional status, cognitive development, and motor development in preschool children). Nutrition and Food Research, $36(1), 62-72$.

Sriningsih. (2017). Keterampilan Renang Gaya Kupu-Kupu Melalui Pendekatan Bermain Dalam Pembelajaran Akuatik . Jurnal Pendidikan Jasmani Dan Olahraga, 2(2), 43-52.

Sungkowo, S., Raharjo, H. P., \& Supriyono. (2012). Pengembangan Pembelajaran Renang Melalui Pendekatan Bermain Motor Boat Estafet. Journal of Physical Education, Sport, Health and Recreations, 1(5), 233-245.

Susanto, B. H., \& Listianingsih, F. (2019). Model Pembelajaran Akuatik Berbasis Permainan Tradisional Untuk Meningkatkan Keterampilan Berenang Siswa Sekolah Dasar. Elementary School, 6, 96-104.

Suwiwa, I. G. (2015). Penerapan Model Pembelajaran Kooperatif Tipe Jigsaw Untuk Meningkatkan Aktivitas Dan Hasil Belajar Mata Kuliah Teori Dan Praktek Renang Ii. JPI (Jurnal Pendidikan Indonesia), 4(2), 666-674. https://doi.org/10.23887/jpi-undiksha.v4i2.6063

Tedi Supriyadi, E. S. (2017). Meningkatkan Variasi Gerak Dasar Dalam Pembelajaran Permainan Rounders Melalui Permainan Target. Sportive, 2(1), $1-10$. 